\title{
Mechanochemically Metamorphosed Composites of Homogeneous Nanoscale Silicon and Silicate Oxides with Lithium and Metal Compounds
}

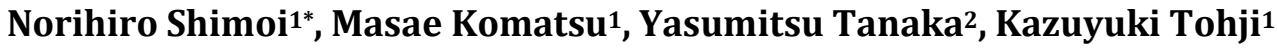 \\ ${ }^{1}$ Graduate School of Environmental Studies, Tohoku University, Sendai, Japan \\ ${ }^{2}$ Institute for Excellence in Higher Education, Tohoku University, Sendai, Japan \\ Email: *norihiro.shimoi.c8@tohoku.ac.jp
}

How to cite this paper: Shimoi, N., Komatsu, M., Tanaka, Y. and Tohji, K. (2018) Mechanochemically Metamorphosed Composites of Homogeneous Nanoscale Silicon and Silicate Oxides with Lithium and Metal Compounds. Materials Sciences and Applications, 9, 111-125.

https://doi.org/10.4236/msa.2018.91008

Received: October 16, 2017

Accepted: January 15, 2018

Published: January 18, 2018

Copyright $\odot 2018$ by authors and Scientific Research Publishing Inc. This work is licensed under the Creative Commons Attribution International License (CC BY 4.0).

http://creativecommons.org/licenses/by/4.0/

(c) $\underset{\mathrm{EY}}{\mathrm{i}}$ Open Access

\begin{abstract}
An active anode material for Li-ion batteries was synthesized using a simple mechanochemical process to minimize the large change in Si volume observed during charge-discharge operation and to compensate for the associated irreversible loss of Li or irreversible capacity loss, which are obstacles to achieve high-performance electrochemical properties during charge-discharge. The composite was mechanochemically milled with $\mathrm{Si}$, lithium oxide, and copper oxide as raw materials; the composite contains Si nanoparticles, amorphous silicon monoxide, and $\mathrm{Si}-\mathrm{Li}$ or $\mathrm{Si}-\mathrm{Cu}$ alloy compounds, and it exhibits improved electrochemical properties. In particular, this composite achieved a better capacity retention, higher coulombic efficiency (over 100\%), and longer cycling performance than Si alone, indicating considerable optimization of the electrical and ionic conductivity in the composite. The developed method allowed for control of the $\mathrm{Li}$ content to compensate for the lack of $\mathrm{Li}$ ions in the composite, and the cycling performance was optimized using the $\mathrm{Cu}$ alloy, oxide, and Li compounds within the composite.
\end{abstract}

\section{Keywords}

Mechanochemical Process, Nanocomposites, Metamorphosed Composites, Lithium-Ion Battery, Silicon Active Material

\section{Introduction}

Si-based Li-ion batteries (LIBs) have great potential because of the high capacity of the Si-based anodes relative to that of graphite anodes [1]. However, a major 
obstacle to achieve a satisfactory reversible capacity in practical use is the large change in the Si volume observed during charge-discharge operations [2] [3] [4] [5] [6] and the irreversible formation of Li components. Many researchers have attempted to overcome these problems using nanostructures [4] [7]-[14] or other approaches, such as partial oxidization [7] [15] [16], composite formation with other materials [7] [9] [11] [17] [18] [19] [20], liquid-phase synthesis, and various battery production methods. Improvements in the stability of the prepared Si anodes have been observed from these attempts, leading to an improvement in LIB performance. We consider that further significant improvements may be obtained from synergistic effects when two or more approaches are simultaneously introduced in a simple operation. Accordingly, we reported the optimization of the cycling properties of an active $\mathrm{Si}$ anode by employing a composite of $\mathrm{Si}$ with $\mathrm{CuO}$ that was formed by a simple ball milling process with a planetary ball mill machine [21]. Here, we propose a mechanochemical approach that involves ball milling with $\mathrm{Si}, \mathrm{Li}_{2} \mathrm{O}$, and $\mathrm{CuO}$, and we describe the mechanism by which the obtained composite achieves a high charge-discharge performance. We successfully synthesized composites using homogeneous, nanoscale $\mathrm{Si}$ grains in a matrix of partially oxidized ground $\mathrm{Si}(\mathrm{SiO})$ as an active material. An LIB using the prepared composite showed a high initial coulombic efficiency (ratio between the reversible discharge capacity and the charge capacity) with good charge-discharge characteristics and an optimized cycling performance of over $3000 \mathrm{mAh} / \mathrm{g}$ after 800 cycles (Figure 1). The prepared composite of $\mathrm{Si}, \mathrm{Li}_{2} \mathrm{O}$, and $\mathrm{CuO}$ shows improved electrical and ionic conductivities in the LIB system and is resistant to crystal collapse because of the expansion and contraction of $\mathrm{Si}$ in the composite. There are many reports of attempts to optimize both the electrical and ionic conductivities [22] [23] [24] [25] [26]; however, there are no previous attempts to synthesis active materials that include $\mathrm{Li}$ atoms to maintain the high performance of an LIB that lacks Li atoms for charge-discharge characteristics. We propose the synthesis of a composite with active Li compounds to compensate for the lack of $\mathrm{Li}$ ions in the anode of an LIB system along with $\mathrm{Li}-\mathrm{Si}$ or other metal-Si alloys to optimize the electrical and ionic conductivities using a simple mechanochemical process.

\section{Experimental}

\subsection{Composite of $\mathrm{Si}, \mathrm{Li}_{2} \mathrm{O}$, and $\mathrm{CuO}$ Particles}

A mixture of $\mathrm{Si}, \mathrm{Li}_{2} \mathrm{O}$, and $\mathrm{CuO}$ particles (i.e. $\mathrm{Si}+\mathrm{Li}_{2} \mathrm{O}+\mathrm{CuO}=2.0 \mathrm{~g}$ ) with average particle diameters of $4 \mu \mathrm{m}$ (Kojundo Chemistry Laboratory Co., Ltd., Japan) was placed in a zirconia mill pot $\left(45 \mathrm{~cm}^{3}\right.$ inner volume) with 7 zirconia balls ( $15 \mathrm{~mm} \varphi$ in diameter); ball milling was performed using a planetary ball mill machine (Fritsch Pulverisette-7) at approximately $600 \mathrm{rpm}$ without heating and in air to produce aggregates composited with $\mathrm{Si}, \mathrm{Li}_{2} \mathrm{O}$, and $\mathrm{CuO}$. We then established a new anode composite to exploit the anticipated mechanochemical reaction between $\mathrm{Si}, \mathrm{Li}_{2} \mathrm{O}$, and $\mathrm{CuO}$ when ground together. We designed particles 


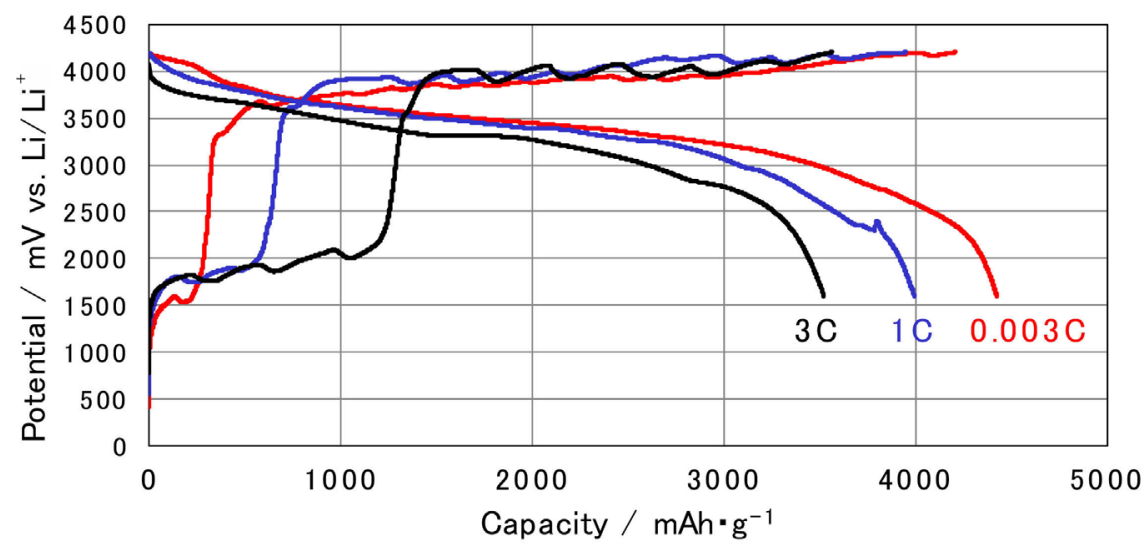

(a)

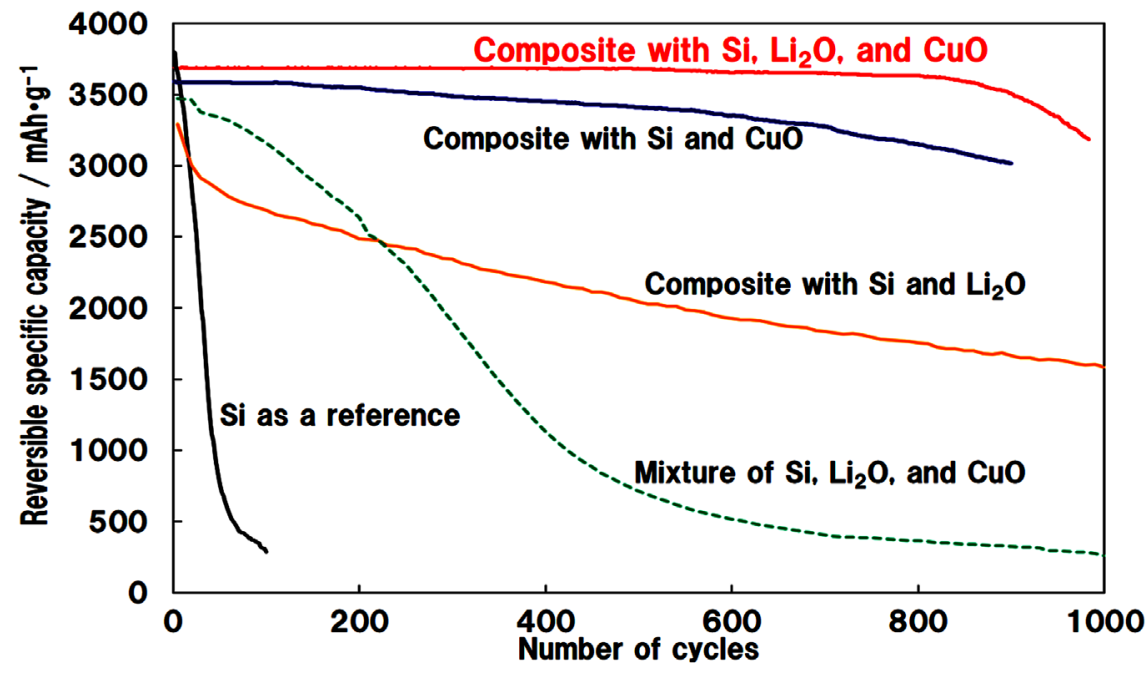

(b)

Figure 1. (a) Initial charge-discharge properties of the prepared composite with $\mathrm{Si}, \mathrm{Li}_{2} \mathrm{O}$, and $\mathrm{CuO}$ at loading current densities of $0.01 \mathrm{~mA} / \mathrm{cm}^{2}(0.003 \mathrm{C}), 3.2 \mathrm{~mA} / \mathrm{cm}^{2}(1 \mathrm{C})$, and $9.6 \mathrm{~mA} / \mathrm{cm}^{2}(3 \mathrm{C})$; (b) Comparison of the cycling properties of the anode with the prepared $\mathrm{Si}, \mathrm{Li}_{2} \mathrm{O}$, and $\mathrm{CuO}$ composite (red line); $\mathrm{Si}$ and $\mathrm{CuO}$ composite (blue line); $\mathrm{Si}$ and $\mathrm{Li}_{2} \mathrm{O}$ composite (green line); $\mathrm{Si}_{1} \mathrm{Li}_{2} \mathrm{O}$, and $\mathrm{CuO}$ mixture (dotted line); and $\mathrm{Si}$ particles as a reference (black line). The attenuation observed for the $\mathrm{Si}, \mathrm{Li}_{2} \mathrm{O}$, and $\mathrm{CuO}$ composite after 800 cycles is due to peeling of the film from the $\mathrm{Cu}$ foil.

composited with $\mathrm{Si}(1.630 \mathrm{~g}), \mathrm{Li}_{2} \mathrm{O}(0.043 \mathrm{~g})$, and $\mathrm{CuO}(0.327 \mathrm{~g})$ for ball milling. The operation time for rotation of the ball mills was $3 \mathrm{~h}$. Partial oxidation of $\mathrm{Si}$ at a molar ratio of $\mathrm{Si}: \mathrm{Li}_{2} \mathrm{O}: \mathrm{CuO}$ of 10:0.25:0.75 endowed the composite with an excellent LIB performance.

\subsection{Preparation of the Composite Electrodes}

The Si composite electrodes were prepared as follows. The prepared composite was mixed with a binder composed of polyamic acid (Ube-kousan KK Company, Japan) and acetylene black (AB; Denkikagaku, Japan) as a conductive material in a 1-methyl-2-pyrrolidone solution. The Si composite:binder:AB weight ratio was 70:20:10. The slurry of the electrode components was cast onto a $\mathrm{Cu}$ 
foil and dried at $70^{\circ} \mathrm{C}$ for $20 \mathrm{~min}$ in air. The cast electrodes were cut to $10 \mathrm{~mm} \varphi$. The obtained electrodes had thicknesses in the range of $40-50 \mu \mathrm{m}$. The electrodes were further dried at $550^{\circ} \mathrm{C}$ under vacuum for $3 \mathrm{~h}$ and then pressed at 200 $\mathrm{kgf} / \mathrm{cm}^{2}$. The specific capacity was calculated according to the weight of the composite/binder/AB. Electrochemical tests of the composite electrodes were conducted using two-electrode test coin cells (type 2032; Housen, Japan) with a separator, and a gasket was used to hold the electrode in place.

\subsection{Assembly of a Test Coin Cell for the LIB}

The coin cells were assembled in an Ar-filled glove box using $1 \mathrm{M} \mathrm{LiPF}_{6}$ in a mixed ethylene carbonate, diethylene carbonate, and dimethyl carbonate solution $(60: 25: 15, \mathrm{v} / \mathrm{v})$ as the electrolyte. For high charge-discharge operations, a $\mathrm{LiCoO}_{2}$-coated film (300- $\mu \mathrm{m}$ thick) at a capacity of $12.0 \mathrm{mAh} / \mathrm{cm}^{2}$ was employed as the cathode counter electrode, whereas a metal Li-foil was employed for impedance measurements. The separator was a polyethylene/polypropylene/polyethylene multi-stacked film with a thickness of $10 \mu \mathrm{m}$. The electrochemical performances of the two-electrode coin cells were evaluated using a potentiostat (Hokuto Denko Co. Ltd., Japan).

\section{Results and Discussion}

\subsection{Electrochemical Properties of the Prepared Composite}

Figure 1(a) shows the electrochemical performance of the composite anode evaluated in a 2032-type coin cell with a $\mathrm{LiCoO}_{2}$ cathode in a constant-current charge-discharge test in the voltage range of $1.6-4.2 \mathrm{~V}$ with current densities of $0.01 \mathrm{~mA} / \mathrm{cm}^{2}(0.003 \mathrm{C}), 3.2 \mathrm{~mA} / \mathrm{cm}^{2}(1 \mathrm{C})$, and $9.6 \mathrm{~mA} / \mathrm{cm}^{2}(3 \mathrm{C})$ at $27^{\circ} \mathrm{C}$. The state of the charge of the battery was set to $100 \%$. An LIB anode composed of $\mathrm{Si}$, $\mathrm{Li}_{2} \mathrm{O}$, and $\mathrm{CuO}$ was fabricated on a $\mathrm{Cu}$ foil with a molar ratio of 10:0.25:0.75 to obtain good experimental charge-discharge characteristics. The results indicate that the charge and reversible discharge capacities depend on the components of the active material. The prepared composite, shown by the red line, exhibited an initial coulombic efficiency of $108.5 \%$ at a current density of $0.01 \mathrm{~mA} / \mathrm{cm}^{2}(0.003$ C), as shown in Figure 1(a). The blue and black lines indicate that the initial coulombic efficiencies were $102.3 \%$ and $99.86 \%$ at current densities of 3.2 $\mathrm{mA} / \mathrm{cm}^{2}(1 \mathrm{C})$ and $9.6 \mathrm{~mA} / \mathrm{cm}^{2}(3 \mathrm{C})$, respectively. The average initial coulombic efficiency of the $\mathrm{Si}$ active material in the LIB was approximately $80 \%$; however, the prepared composite attained a value of over $99 \%$ with a high loading rate. The Li compounds in the prepared composite may optimize the charge-discharge properties. We previously reported a mechanochemically synthesized composite of $\mathrm{Si}$ and $\mathrm{CuO}$ with a high initial coulombic efficiency of 95.1\% [21]. The addition of $\mathrm{Li}$ ions is expected to improve the electrical and ionic conductivities of the active material. Moreover, because ceramic $\mathrm{CuO}$ and $\mathrm{Li}_{2} \mathrm{O}$ are known as non-occlusive and non-conductive materials, respectively, they do not function as active materials in the LIB. In this study, the composites, which consist of ag- 
gregates of $\mathrm{Si}$, other conductive nanoscale grains, and a $\mathrm{Si}$ oxide material produced mechanochemically by ball milling, were successfully employed as anodes to occlude Li ions with a high coulombic efficiency from the first charge-discharge stage.

Figure $1(\mathrm{~b})$ shows the cycling properties in the voltage range of $1.6-4.2 \mathrm{~V}$ at a current density of $9.6 \mathrm{~mA} / \mathrm{cm}^{2}(3 \mathrm{C})$ with $\mathrm{LiCoO}_{2}$ employed as the cathode in a coin cell. The measured anodes employ a composite of $\mathrm{Si}, \mathrm{Li}_{2} \mathrm{O}$, and $\mathrm{CuO}$ produced by a mechanochemical process (red line), a composite of $\mathrm{Si}$ and $\mathrm{CuO}$ (blue line), a composite with $\mathrm{Si}$ and $\mathrm{Li}_{2} \mathrm{O}$ (yellow line), a mixture of $\mathrm{Si}, \mathrm{Li}_{2} \mathrm{O}$, and $\mathrm{CuO}$ (dotted yellow line), and Si particles as a reference (black line). The $\mathrm{Si} / \mathrm{Li}_{2} \mathrm{O} / \mathrm{CuO}$ and $\mathrm{Si} / \mathrm{CuO}$ composites exhibited reversible capacities above 3000 $\mathrm{mAh} / \mathrm{g}$ after 800 cycles; notably, the $\mathrm{Si} / \mathrm{Li}_{2} \mathrm{O} / \mathrm{CuO}$ composite showed a high reversible capacity at 1000 cycles. This result contrasts with the behaviour of bare Si particles and the mixtures of $\mathrm{Si} / \mathrm{CuO}$ and $\mathrm{Si} / \mathrm{Li}_{2} \mathrm{O}$, which showed capacities below $50 \%$ after relatively few cycles. The $\mathrm{Li}_{2} \mathrm{O}$ and $\mathrm{CuO}$ ceramics in the mixture do not function as active materials and have low cycling properties when mixed with $\mathrm{Si}$, as shown in Figure 1(b). However, the $\mathrm{Si} / \mathrm{Li}$ and $\mathrm{Si} / \mathrm{Cu}$ compounds synthesized using the ball milling process with this mixture increase the electrical and ionic conductivities in the prepared composite, thereby helping to maintain a high capacity over 100 charge-discharge cycles.

\subsection{Mechanochemical Composition}

Mechanochemical processes have been widely studied [27] [28] [29]. One line of research has focused on mechanochemical reduction by employing one element and one compound [30] [31], such as the reduction of $\mathrm{CuO}$ by co-grinding with $\mathrm{Al}, \mathrm{Mg}$, or $\mathrm{Si}$ to form $\mathrm{Cu}$ powders [32]. However, the products obtained using equimolar $\mathrm{CuO}$ and $\mathrm{Si}$ fail to achieve high LIB performances because a Si oxide, probably $\mathrm{SiO}_{2}$, synthesized by the mechanochemical process leads to excessive oxide atoms in $\mathrm{Si}$, and the composite does not function as an active material. In contrast, at a molar ratio of 10:0.75, Si was partially oxidized by the oxide atoms in $\mathrm{CuO}$, producing a composite with an excellent LIB performance. In this case, the chemical reaction between $\mathrm{Si}$ and $\mathrm{CuO}$ is given by Equation (1). Thus, we attempted to establish a new anode composite to exploit the anticipated mechanochemical reaction between $\mathrm{Si}$ and $\mathrm{CuO}$ upon ball milling.

$$
3 \mathrm{CuO}+4 \mathrm{Si} \rightarrow \mathrm{Cu}_{3} \mathrm{Si}+3 \mathrm{SiO}
$$

Furthermore, the mechanochemical reaction between $\mathrm{Si}$ and $\mathrm{Li}_{2} \mathrm{O}$ when mixed at a molar ratio of 10:0.25 ( $\mathrm{Si}: \mathrm{O})$ is expected to produce a composite by a non-equilibrium active reaction. Li has a lower electronegativity than $\mathrm{Si}$ or $\mathrm{Cu}$ formed by a mechanochemical process [32], does not react to reduce oxide atoms, and is not mechanochemically synthesized.

Figure 2 shows the crystallinity and ratio of components with Li atoms for the composite obtained by the mechanochemical process of $\mathrm{Si}, \mathrm{Li}_{2} \mathrm{O}$, and $\mathrm{CuO}$. The oxide atoms in $\mathrm{CuO}$ are reduced, and residual $\mathrm{Cu}$ is expected to form an alloy 


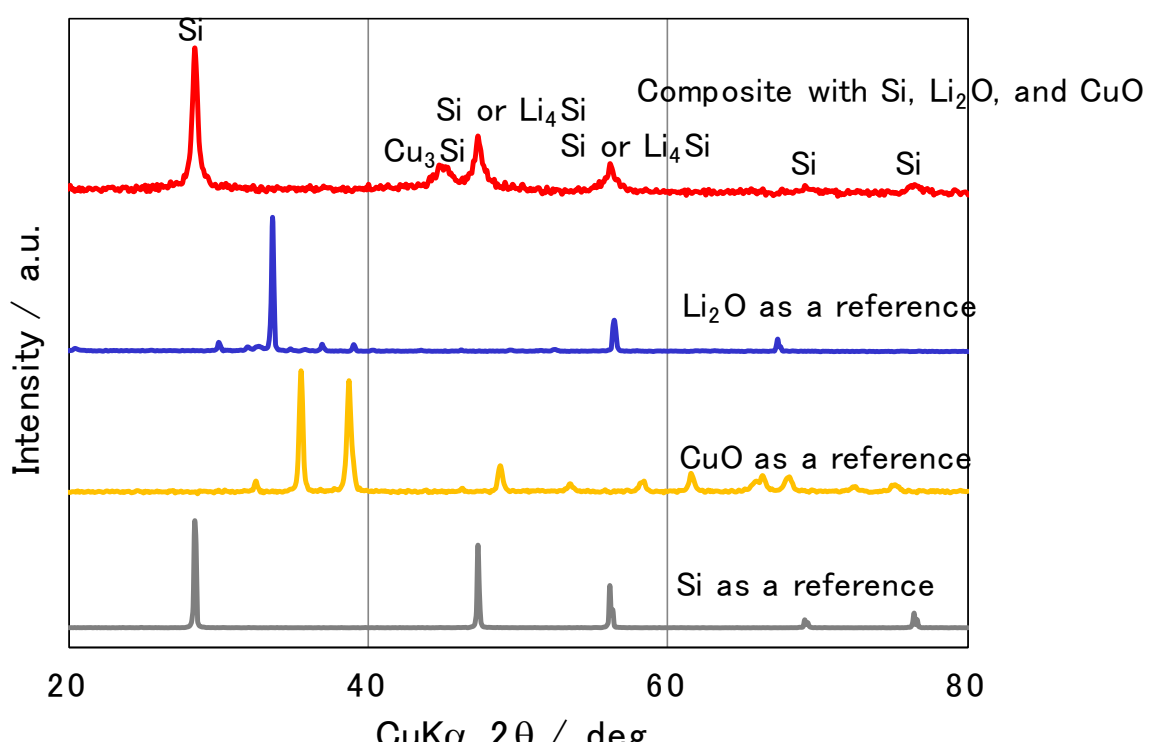

(a)

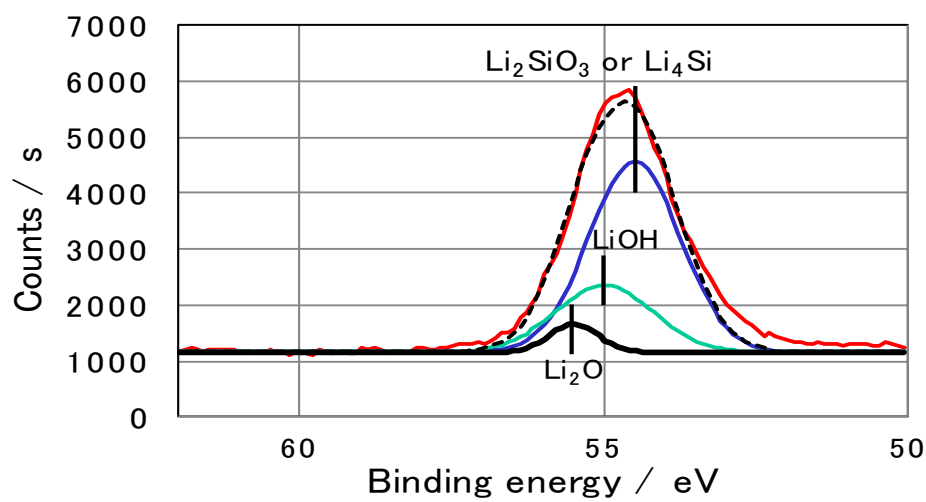

(b)

Figure 2. (a) XRD patterns of the $\mathrm{Si}, \mathrm{Li}_{2} \mathrm{O}$, and $\mathrm{CuO}$ composite and each raw material before the ball milling process; (b) XPS spectrum of the prepared composite, enlarged in the region of the Li peak from 50 to $60 \mathrm{eV}$. The red spectrum can be deconvoluted into peaks corresponding to $\mathrm{Li}$ ions with various oxidation numbers. The $\mathrm{Li}$ ion peak mainly consists of $\mathrm{Li}_{2} \mathrm{SiO}_{3}$ or $\mathrm{Li}_{4} \mathrm{Si}$ (blue line), with minor $\mathrm{LiOH}$ (aqua line) and $\mathrm{Li}_{2} \mathrm{O}$ (black line) components.

with Si [27]. According to the X-ray diffraction (XRD; Rigaku Co. Ltd., Japan) pattern in Figure 2(a), the $\mathrm{Cu}-\mathrm{Si}$ alloy is in the form of $\mathrm{Cu}_{3} \mathrm{Si}$ [33] and acts as a current collector; this alloy is electrically conductive and an important material for charge-discharge characteristics, which is determined by comparing the $\mathrm{Si} / \mathrm{Li}_{2} \mathrm{O} / \mathrm{CuO}$ composite with the $\mathrm{Si} / \mathrm{Li}_{2} \mathrm{O}$ composite in Figure 1 (b), but does not function as an active material. In the XRD spectrum of the composite, no peaks are observed for $\mathrm{CuO}$ and $\mathrm{Li}_{2} \mathrm{O}$. Thus, the compounds synthesized from the reduction and oxidation of $\mathrm{CuO}$ or $\mathrm{Li}_{2} \mathrm{O}$ were amorphous in the prepared composite. $\mathrm{Si}, \mathrm{Li}$, and the other oxide compounds were examined using high-resolution Si2p X-ray photoelectron spectroscopy (XPS; JEOL, Japan); a spectrum of the synthesized composite is shown in Figure 2(b). A Si-Li oxide or $\mathrm{Si}-\mathrm{Li}$ alloy is 
expected to exist in the $\mathrm{Si}, \mathrm{Li}_{2} \mathrm{O}$, and $\mathrm{CuO}$ composite. The enlargement of the XPS peak at $\sim 50-60 \mathrm{eV}$, shown in Figure 2(b), indicates the presence of a variety of Li ions with different oxidation numbers and mainly consists of Li-silicate oxide materials and $\mathrm{Li}$ alloys, namely $\mathrm{Li}_{2} \mathrm{SiO}_{3}, \mathrm{Li}_{4} \mathrm{Si}, \mathrm{LiOH}$, and $\mathrm{Li}_{2} \mathrm{O}$. The content ratio of the different $\mathrm{Li}$ components in the composite was calculated by deconvolution of the peak position, which was calibrated using the C1s signal. Li was found mainly in the form of $\mathrm{Li}_{2} \mathrm{SiO}_{3}$ or $\mathrm{Li}_{4} \mathrm{Si}$ throughout the synthesized composite, which confirms the presence of a Li-silicate oxide and $\mathrm{Li}$-Si alloy in the composite, and the reaction outlined in Equation (2) is presumed. Moreover, $\mathrm{CuO}$ and $\mathrm{Li}_{2} \mathrm{O}$ do not react with each other to form other components.

$$
3 \mathrm{Li}_{2} \mathrm{O}+2 \mathrm{Si} \rightarrow \mathrm{Li}_{2} \mathrm{SiO}_{3}+\mathrm{Li}_{4} \mathrm{Si}
$$

$\mathrm{Li}_{2} \mathrm{SiO}_{3}$ has a higher free energy of formation than $\mathrm{Li}_{2} \mathrm{O}$ and easily decomposes to a $\mathrm{Si}-\mathrm{Li}$ oxide or $\mathrm{Si}-\mathrm{Li}$ alloy; furthermore, $\mathrm{Li}_{2} \mathrm{SiO}_{3}$ does not function as an $\mathrm{LIB}$ active material.

Figure 3 shows an analysis of the prepared composite using scanning electron microscopy, scanning transmission electron microscopy, and transmission electron microscopy (SEM/STEM/TEM; Hitachi High-Technologies Co. Ltd.,
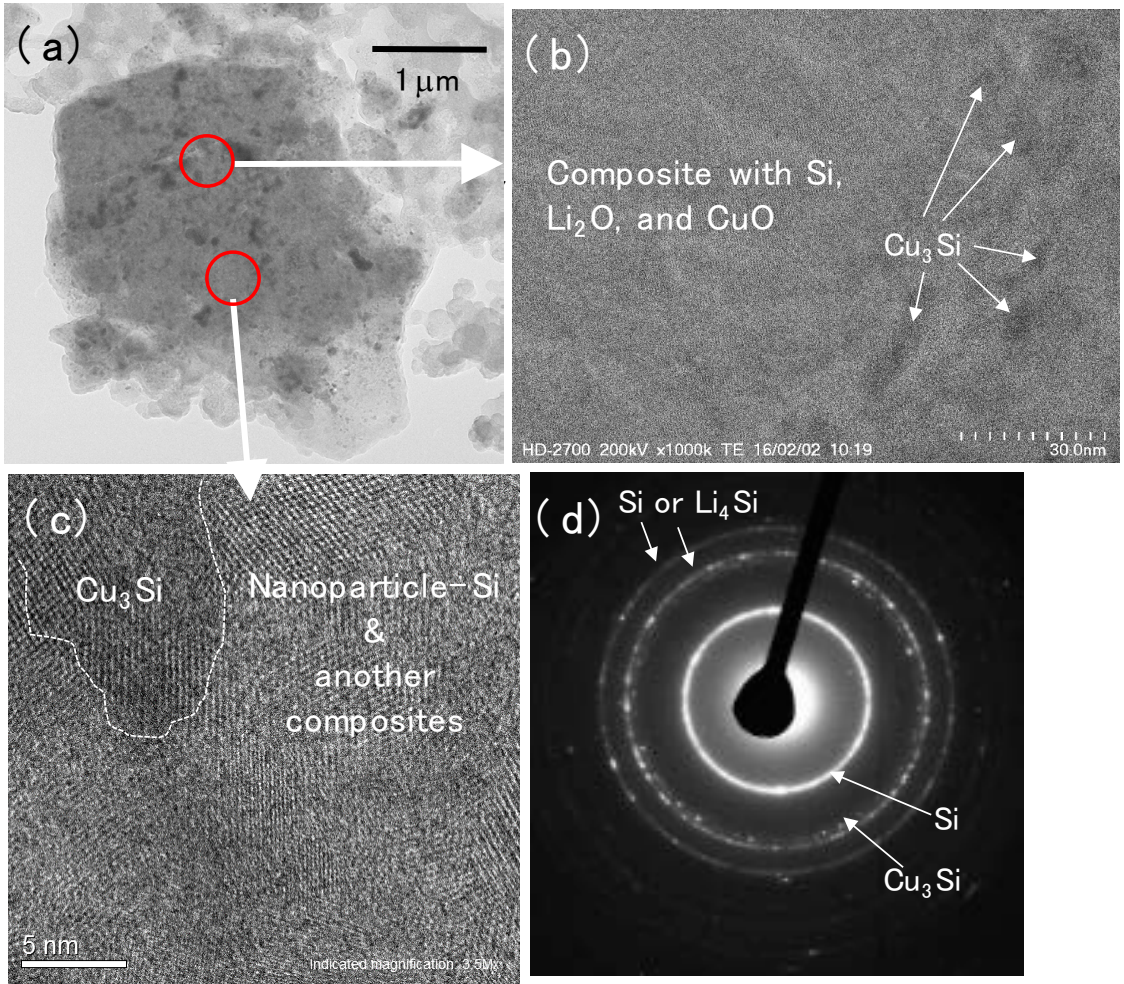

Figure 3. STEM images of the $\mathrm{Si}_{1} \mathrm{Li}_{2} \mathrm{O}$, and $\mathrm{CuO}$ composite. (a) SEM image showing the cross-sectional view of the microscale particles obtained by the ball milling process with $\mathrm{Si}, \mathrm{Li}_{2} \mathrm{O}$, and $\mathrm{CuO}$; (b) STEM cross-sectional view of the composite particle; (c) Enlarged STEM image of the areas marked in (a). The black area inside the white dotted line indicates $\mathrm{Cu}_{3} \mathrm{Si}$ alloy grains in the composite particle; (d) TEM diffraction image showing the diffraction patterns of $\mathrm{Si}, \mathrm{Si}-\mathrm{Li}$ alloy, and $\mathrm{Cu}-\mathrm{Si}$ alloy compounds in the STEM measurement area of (c). 
Japan). The SEM overview image (Figure 3(a)) reveals the composite particles obtained by the ball milling process with $\mathrm{Si}, \mathrm{Li}_{2} \mathrm{O}$, and $\mathrm{CuO}$, and the STEM cross-sectional views in Figure 3(b) and Figure 3(c) show the bright field images of an anode electrode film in the areas indicated by red circles in Figure 3(a). The bright grey areas in these images correspond to the composite of $\mathrm{Si}, \mathrm{Li}$, and $\mathrm{O}$ atoms, whereas the dark grey areas indicate the presence of $\mathrm{Cu}_{3} \mathrm{Si}$ in the composite [21]. The crystal lattices indicate the orientation of each nanoscale Si or $\mathrm{Li}_{4} \mathrm{Si}$, and $\mathrm{Cu}_{3} \mathrm{Si}$ crystal lattice from the results in Figure 2(a). The high-resolution STEM images in Figure 3(c) confirm that each grain has a random crystal orientation and that the composite mainly comprises polycrystalline $\mathrm{Si}$ with nanoscale grains averaging $10 \mathrm{~nm} \varphi$ or $\mathrm{Si}-\mathrm{Li}$ alloy grains, $\mathrm{Cu}_{3} \mathrm{Si}$ nanoscale grains, and other compounds including a silicone monoxide and Li-silicate oxide components. Figure 3(d) represents crystallization of the prepared composite, nanoscale $\mathrm{Si}$ grains, and $\mathrm{Cu}_{3} \mathrm{Si}$ grains.

The presence of $\mathrm{Li}$ or $\mathrm{Cu}$ in the composite is hypothesized to improve the electrical and ionic conductivities of the composite. Thus, impedance measurements were carried out to identify the elements that improve the electrical and ionic conductivities. Figure 4 shows the impedance measurement results for the $\mathrm{Si} / \mathrm{Li}_{2} \mathrm{O} / \mathrm{CuO}, \mathrm{Si} / \mathrm{Li}_{2} \mathrm{O}$, and $\mathrm{Si} / \mathrm{CuO}$ composites, with that for Si particles as a reference. The samples were evaluated in a 2032-type coin cell with metal Li foil as the cathode. The $\mathrm{Si} / \mathrm{Li}_{2} \mathrm{O} / \mathrm{CuO}$ and $\mathrm{Si} / \mathrm{Li}_{2} \mathrm{O}$ composites, which include $\mathrm{Li}$ compounds, do not have a capacitance element in the impedance chart in Figure 4(a) in the low resistance range (shaded area), meaning that the ionic resistance element is almost zero when $\mathrm{Li}$ ions pass into the composite. Moreover, the impedance elements in Figure 4(b) in the high resistance range (shaded area) show that the composites including $\mathrm{Li}$ atoms have lower impedance elements, and the electrical conductance and ionic conductance are better than those of the other

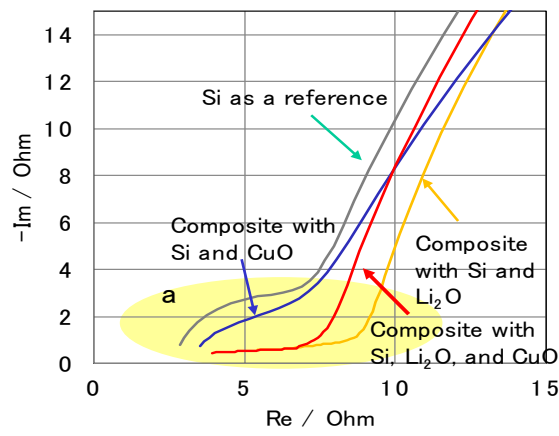

(a)

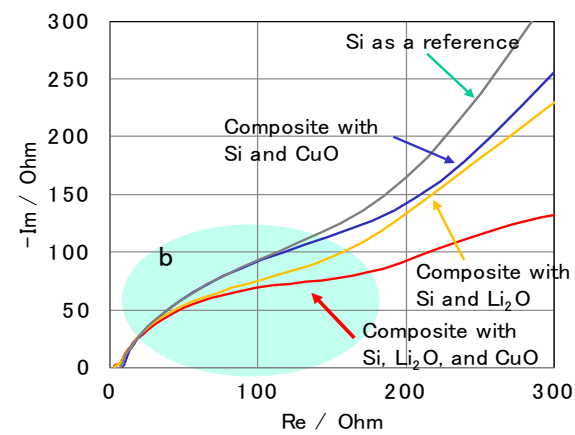

(b)

Figure 4. Comparison of the impedance charts of the composites with $\mathrm{Si}, \mathrm{Li}_{2} \mathrm{O}$, and $\mathrm{CuO}$ (red line), $\mathrm{Si}$ and $\mathrm{Li}_{2} \mathrm{O}$ (yellow line), and $\mathrm{Si}$ and $\mathrm{CuO}$ (blue line), with $\mathrm{Si}$ as a reference (green line). The shaded area of the impedance chart in (a) with a low resistance $(<15 \Omega)$ indicates the electrical and ionic conductivities of a $\mathrm{Li}$ ion passing into a particle and is modelled as a parallel circuit of capacitance and resistance. The shaded area of the chart in (b) with a high resistance $(<300 \Omega)$ indicates the impedance component passing through the border of a particle or from one particle to another. 
composites that do not include $\mathrm{Li}$ atoms. These results confirm that the presence of Li compounds in the composite serve to improve the mobility of electrons and Li ions within the composite in LIBs.

\subsection{Electrochemical Mechanism of the Composite}

We observed punctate materials in the composite, leading us to surmise that the composite is a mixture of compounds of $\mathrm{Si}, \mathrm{Li}_{2} \mathrm{O}$, and $\mathrm{CuO}$. The atomic distributions of $\mathrm{Si}$ and $\mathrm{Cu}$ were determined using energy dispersive $\mathrm{X}$-ray spectroscopy (EDX; Hitachi High-Technologies Corporation, Japan), and the reference Si atoms and $\mathrm{Li}$ atoms were detected using electron energy loss spectroscopy (EELS; Hitachi High-Technologies Corporation, Japan), as shown in Figure 5. Each distribution was measured before the initial charge and after 800 cycles. The EDX and EELS results show that the composite contained $\mathrm{Si}, \mathrm{Li}$, and $\mathrm{Cu}$ grains before the initial charge from the mechanochemical process. $\mathrm{Si}, \mathrm{Li}$, and $\mathrm{Cu}$ were homogeneously dispersed in the composite before the initial charge; after 800 cycles, $\mathrm{Li}$ atoms were practically non-existent in the composite. Li atoms in the composite could be used to discharge the capacity of the anode during charge-discharge operation to maintain a high capacity. In that case, an irreversible Li-Si alloy was synthesized during the charge-discharge process, and the synthesized $\mathrm{Li}$ atoms in the composite were made available to compensate for the capacity attenuation over many cycles. Moreover, a major obstacle to achieving a satisfactory reversible capacity in practical use lies in the large change in the Si volume observed during charge-discharge operation. The shape
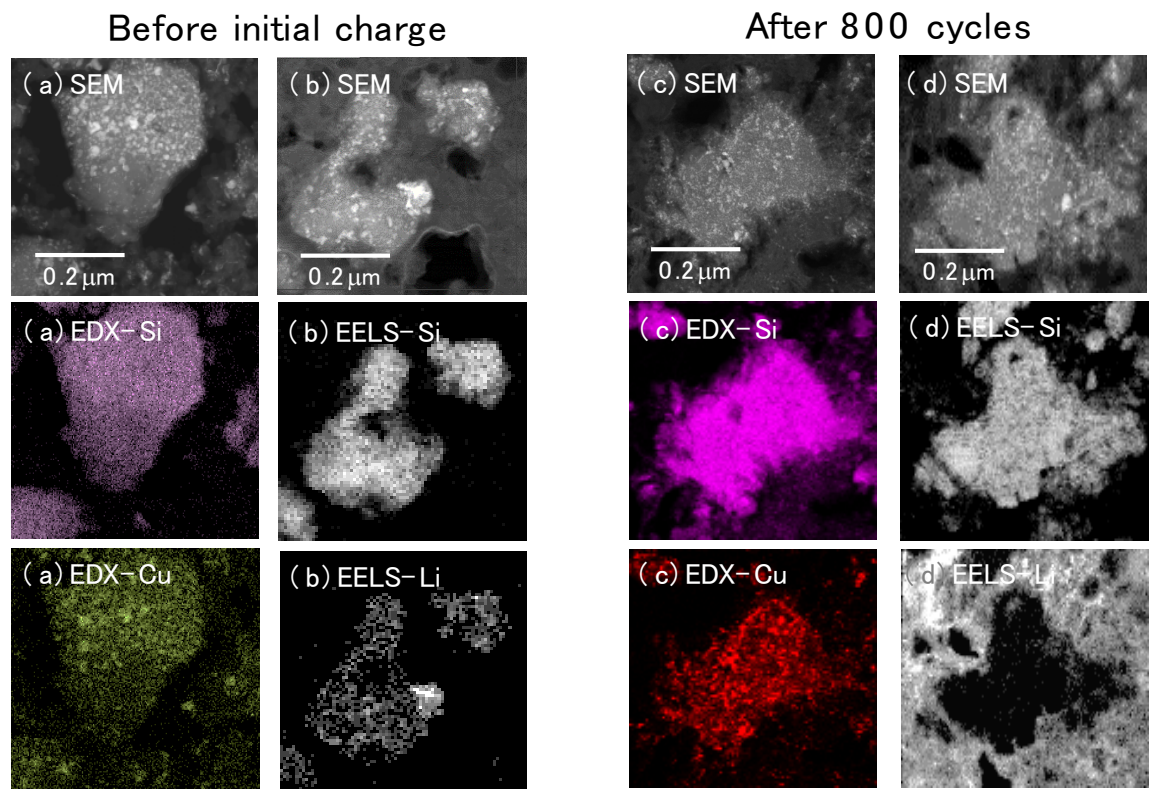

Figure 5. Distributions of $\mathrm{Si}$ and $\mathrm{Cu}$ by EDX and $\mathrm{Si}$ and Li by EELS in the composite with $\mathrm{Si}, \mathrm{Li}_{2} \mathrm{O}$, and $\mathrm{CuO}$. ((a) and (b)) SEM cross-sectional views of the composite with $\mathrm{Si}, \mathrm{Li}_{2} \mathrm{O}$, and $\mathrm{CuO}$ before the initial charge, EDX distribution maps of $\mathrm{Si}$ and $\mathrm{Cu}$, and EELS distribution maps of Si and Li. ((c) and (d)) SEM cross-sectional view of the composite with $\mathrm{Si}$, $\mathrm{Li}_{2} \mathrm{O}$, and $\mathrm{CuO}$; EDX and EELS maps after 800 charge-discharge cycles at $3000 \mathrm{mAh} / \mathrm{g}$. 
of the composite and atomic distributions of $\mathrm{Si}, \mathrm{Li}$, and $\mathrm{Cu}$ were maintained during the testing cycles, and no collapse of the structure was observed in the presence of $\mathrm{SiO}$ as a buffer matrix. The amorphous structure of $\mathrm{SiO}$ [34] [35] [36] [37] in the composite is expected to play a role in mitigating the expansion of active materials with nano-Si grains and including $\mathrm{Li}$ ions. In addition, Figure 5(c) and Figure 5(d) confirm that the composite did not change volume after the charge-discharge process, and crystal or nanoscale grain collapse was prevented during the expansion and contraction of $\mathrm{Si}$ in the prepared composite. In (d), EELS-Li revealed Li atoms distributed around the composite particle because $\mathrm{Li}$ atoms precipitated from the residual electrolyte in the LIB.

The specific gravity of the prepared composite is approximately $2.12 \mathrm{~g} / \mathrm{cm}^{3}$, which is less than the specific gravity of $S i\left(2.33 \mathrm{~g} / \mathrm{cm}^{3}\right)$. The prepared composite contains a matrix of silicon monoxide as a buffer material to maintain the expansion of the composite when inserting Li ions into Si nanoparticles and other active materials. This could prevent the expansion of $\mathrm{Si}$ and optimise the charge-discharge characteristics.

We expect a $\mathrm{Li}$-Si alloy (likely $\mathrm{Li}_{4} \mathrm{Si}$ ) to be present in the composite; $\mathrm{Li}$ ion distribution in the prepared composite is demonstrated by the EDX measurements shown in Figure 5. Thus, the $\mathrm{Si}, \mathrm{Li}_{2} \mathrm{O}$, and $\mathrm{CuO}$ composite is confirmed as an aggregate of nanoscale grains based on $\mathrm{Si}, \mathrm{Cu}_{3} \mathrm{Si}$, and other materials. The structure of the composite is hypothesized in Figure 6 to involve nanoscale Si grains to prevent cracking through numerous repetitions of the charge-discharge cycle [10] [13], $\mathrm{Cu}_{3} \mathrm{Si}$ as a current collector, and amorphous $\mathrm{SiO}$ surrounding each $\mathrm{Si}$ grain to prevent cracking of $\mathrm{Si}$.

We postulate that a composite material consisting of a poly-Si, $\mathrm{Si}$ oxide, $\mathrm{Si}-\mathrm{Cu}$ alloy, $\mathrm{Si}-\mathrm{Li}$ alloy, and $\mathrm{Li}$-silicate oxide in a composite particle will likely

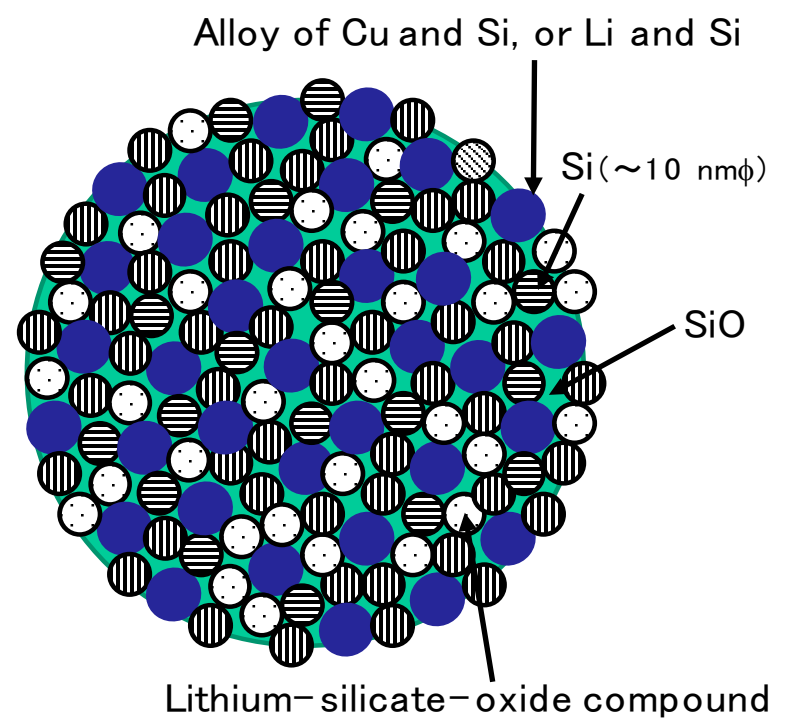

Figure 6. Structural image of the $\mathrm{Si}, \mathrm{Li}_{2} \mathrm{O}$, and $\mathrm{CuO}$ composite as an aggregate of $\mathrm{Si}$ and $\mathrm{Cu}_{3} \mathrm{Si}$ nanoscale grains on amorphous silicon monoxide with a $\mathrm{Li}$-silicate oxide compound (likely $\mathrm{Li}_{2} \mathrm{SiO}_{3}$ ) and a $\mathrm{Li}-\mathrm{Si}$ alloy (likely $\mathrm{Li}_{4} \mathrm{Si}$ ). 
yield a good performance with respect to the charge-discharge characteristics in an LIB. The alloying of $\mathrm{Li}$ or $\mathrm{Cu}$ by mechanochemical processing can transform $\mathrm{Si}$ into a Si alloy or other oxide compound. Improvements in the stability of the $\mathrm{Si}$ anodes have been observed from such individual attempts, leading to improvements in the LIB performance [38] [39] [40]. We consider that further significant improvements will be obtained from synergistic effects when two or more approaches are simultaneously introduced in one simple operation.

\section{Summary and Outlook}

We produced a model for the high electrochemical performance of LIBs employing a $\mathrm{Si}, \mathrm{Li}_{2} \mathrm{O}$, and $\mathrm{CuO}$ composite as an anode material. A high coulombic efficiency of over $100 \%$ and long cycling stability at a high loading current density of $3000 \mathrm{mAh} / \mathrm{g}$ were achieved, indicating that the composite acted as an active material with dispersed $\mathrm{Si}$ nanoscale grains or $\mathrm{Li}-\mathrm{Si}$ compounds. $\mathrm{Li}-\mathrm{Si}$ or $\mathrm{Cu}$-Si alloys are expected to function electrochemically in the charge-discharge process. The $\mathrm{Cu}_{3} \mathrm{Si}$ alloy in the prepared composite helps to improve the electrical conductivity; Li-Si compounds, which include $\mathrm{Li}_{4} \mathrm{Si}$ and $\mathrm{Li}_{2} \mathrm{SiO}_{3}$, work to improve the electrical conductivity and compensate for the lack of $\mathrm{Li}$ ions in the composite during charge-discharge cycling. The diffusion of $\mathrm{Li}^{+}$into the composite that includes nano-Si grains, $\mathrm{SiO}, \mathrm{Li}_{2} \mathrm{SiO}_{3}, \mathrm{Cu}_{3} \mathrm{Si}$, and $\mathrm{Li}_{4} \mathrm{Si}$ in (a) of Figure 7 results in an initial charge of the $\mathrm{LIB}$, and an alloy of $\mathrm{Li}-\mathrm{Si}$ or $\mathrm{SiO}$ is synthesized in the composite in (b), as well as an irreversible Si-Li alloy, which does not participate in the charge-discharge process. Furthermore, the $\mathrm{Li}$ ions remove $\mathrm{SiO}$ and some $\mathrm{Li}_{4} \mathrm{Si}$ from nano-Si in (c), and the composited $\mathrm{Li}_{4} \mathrm{Si}$ is transformed to $\mathrm{Li}_{4-\mathrm{y}} \mathrm{Si}$. In (d), $\mathrm{Li}_{4-\mathrm{y}} \mathrm{Si}$ receives $\mathrm{Li}$ atoms from $\mathrm{Li}_{2} \mathrm{SiO}_{3}$, which has a higher free energy of formation. The next charge occurs in (e). $\mathrm{Li}_{2} \mathrm{SiO}_{3}$ and $\mathrm{Li}_{4} \mathrm{Si}$ in the composite may not be the actual compounds found in the composite because

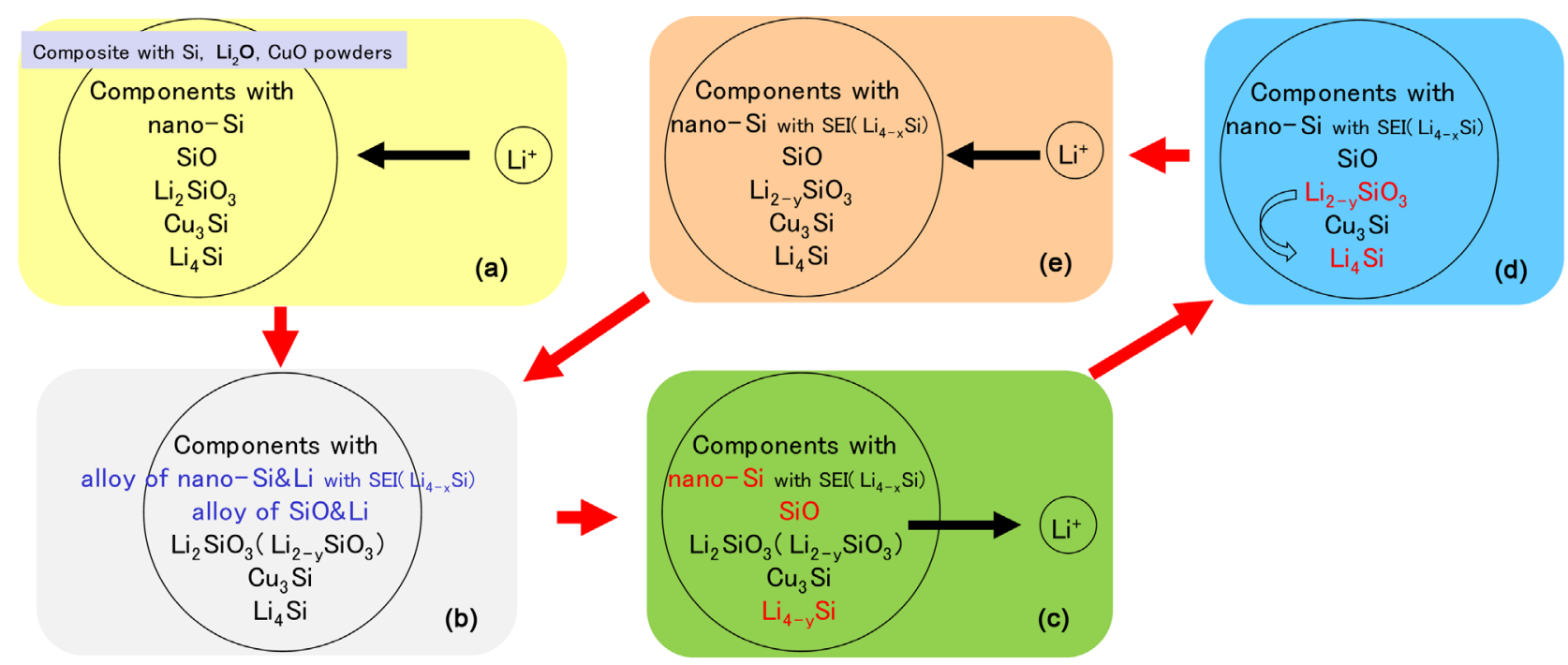

Figure 7. Model of a charge-discharge mechanism employing the composite with $\mathrm{Si}, \mathrm{Li}_{2} \mathrm{O}$, and $\mathrm{CuO}$ to satisfy the high capacity and long cycling stability of the active anode material. 
each material is assumed to be mixed as amorphous materials. Nonetheless, compounds in the composite that include $\mathrm{Li}$ atoms, such as $\mathrm{Li}_{2} \mathrm{SiO}_{3}$ and $\mathrm{Li}_{4} \mathrm{Si}$, are consumed before and after the charge-discharge process, and Li atoms are expected to be available to compensate for the lack of $\mathrm{Li}$ ions in the anode of the LIB.

We conclude that the structure of the composite unites the structural features of an active material based on a Si composite with a high capacity and cyclic reversible charge properties. The following observations were made:

1) A homogeneous dispersion of $\mathrm{Cu}_{3} \mathrm{Si}$ nanoscale grains, $\mathrm{Si}$ nanoparticles, amorphous $\mathrm{SiO}$, and $\mathrm{Si}-\mathrm{Li}$ compounds was obtained using a simple mechanochemical process. The crystals of both $\mathrm{Cu}_{3} \mathrm{Si}$ and $\mathrm{Si}$ nanoparticles align randomly when ground at $27^{\circ} \mathrm{C}$ in air.

2) Our prepared composite delivered a better capacity retention and coulombic efficiency (over 100\%) than Si alone. The ground samples exhibited a better cycling ability than the simple mixtures, and we could show that the existence of a $\mathrm{Si}-\mathrm{Cu}$ alloy, $\mathrm{SiO}$, and $\mathrm{Si}-\mathrm{Li}$ compounds in the composite are important factors for improving the cycling performance. Moreover, the electrochemical stability of $\mathrm{Si}$ with $\mathrm{Cu}_{3} \mathrm{Si}, \mathrm{Li}_{2} \mathrm{SiO}_{3}$, and $\mathrm{Li}_{4} \mathrm{Si}$ synthesized by a ball milling process was important in controlling the cycling performance. We expect the controlled release of $\mathrm{Li}$ from the $\mathrm{Li}$ compounds formed in the composite to compensate for the lack of $\mathrm{Li}$ ions and $\mathrm{Si}$ oxide compounds in the composite and thus optimize the cycling performance.

Thus, we synthesized an active composite material to serve as an anode in an LIB using a simple mechanochemical process. Successful material preparation for a $\mathrm{Si}$ anode was performed with a smaller addition of $\mathrm{CuO}$ as a nonstoichiometric case, expanding our understanding toward mechanochemical processes. While optimizing our treating conditions for preparing the Si composite, we considered the different applications of nonstoichiometric reactions to other similar issues.

\section{Acknowledgements}

We kindly thank DOWA Holdings Corporation for their help in the construction and electrochemical measurements of the composite employed in this study.

\section{References}

[1] Netz, A., Huggins, R.A. and Weppner, W. (2003) The Formation and Properties of Amorphous Silicon as Negative Electrode Reactant in Lithium Systems. Journal of Power Sources, 119-121, 95-100. https://doi.org/10.1016/S0378-7753(03)00132-0

[2] Besenhard, J.O. (1999) Handbook of Battery Materials, Wiley-VCH, Weinheim.

[3] Huggins, R.A. (1989) Materials Science Principles Related to Alloys of Potential Use in Rechargeable Lithium Cells. Journal of Power Sources, 26, 109-120. https://doi.org/10.1016/0378-7753(89)80020-5

[4] Obrovac, M.N. and Krause, L.J. (2007) Reversible Cycling of Crystalline Silicon Powder. Journal of Electrochemical Society, 154, A103-A108. 
https://doi.org/10.1149/1.2402112

[5] Liu, X.H., et al. (2012) Size-Dependent Fracture of Silicon Nanoparticles during Lithiation. ACS Nano, 6, 1522-1531. https://doi.org/10.1021/nn204476h

[6] Zhao, K., et al. (2012) Concurrent Reaction and Plasticity during Initial Lithiation of Crystalline Silicon in Lithium-Ion Batteries. Journal of Electrochemical Society, 159, A238-A243. https://doi.org/10.1149/2.020203jes

[7] Hu, Y.-S., et al. (2008) Superior Storage Performance of a $\mathrm{Si} @ S i O_{\mathrm{x}} / \mathrm{C}$ Nanocomposite as Anode Material for Lithium-Ion Batteries. Angewandte Chemie, 47, 1645 1649. https://doi.org/10.1002/anie.200704287

[8] Kovalenko, I., et al. (2011) A Major Constituent of Brown Algae for Use in HighCapacity Li-Ion Batteries. Science, 334, 75-79. https://doi.org/10.1126/science.1209150

[9] Magasinski, A., et al. (2010) High-Performance Lithium-Ion Anodes Using a Hierarchical Bottom-Up Approach. Nature Materials, 9, 353-358.

https://doi.org/10.1038/nmat2725

[10] Szczech, J.R. and Jin, S. (2011) Nanostructured Silicon for High Capacity Lithium Battery Anodes. Energy \& Environmental Science, 4, 56-72. https://doi.org/10.1039/C0EE00281J

[11] Liu, N., et al. (2012) A Yolk-Shell Design for Stabilized and Scalable Li-Ion Battery Alloy Anodes. Nano Letters, 12, 3315-3321. https://doi.org/10.1021/nl3014814

[12] Hu, L., et al. (2011) Si Nanoparticle-Decorated Si Nanowire Networks for Li-Ion Battery Anodes. Chemical Communications, 47, 367-369. https://doi.org/10.1039/C0CC02078H

[13] Holzapfel, M., et al. (2006) Nano Silicon for Lithium-Ion Batteries. Electrochimica Acta, 52, 973-978. https://doi.org/10.1016/j.electacta.2006.06.034

[14] McDowell, M.T., et al. (2012) Studying the Kinetics of Crystalline Silicon Nanoparticle Lithiation with in Situ Transmission Electron Microscopy. Advanced Materials, 24, 6034-6041. https://doi.org/10.1002/adma.201202744

[15] Yang, J., et al. (2002) $\mathrm{SiO}_{\mathrm{x}}$-Based Anodes for Secondary Lithium Batteries. Solid State Ionics, 152-153, 125-129. https://doi.org/10.1016/S0167-2738(02)00362-4

[16] Shimoi, N. and Tanaka, Y. (2012) Improvement in Si Active Material Particle Performance for Lithium-Ion Batteries by Surface Modification of an Inductivity Coupled Plasma-Chemical Vapor Deposition. Electrochimica Acta, 80, 227-232. https://doi.org/10.1016/j.electacta.2012.07.006

[17] Hochgatterer, N.S., et al. (2008) Silicon/Graphite Composite Electrodes for HighCapacity Anodes: Influence of Binder Chemistry on Cycling Stability. Electrochemical and Solid-State Letters, 11, A76-A80. https://doi.org/10.1149/1.2888173

[18] Jang, B.O., et al. (2013) Electrospun Co-Sn Alloy/Carbon Nanofibers Composite Anode for Lithium Ion Batteries. Journal of Alloys and Compounds, 574, 335-340. https://doi.org/10.1016/j.jallcom.2013.05.063

[19] Wu, H., et al. (2012) Stable Cycling of Double-Walled Silicon Nanotube Battery Anodes through Solid-Electrolyte Interphase Control. Nature Nanotechnology, 7, 309-315. https://doi.org/10.1038/nnano.2012.35

[20] Ebner, M., et al. (2013) Visualization and Quantification of Electrochemical and Mechanical Degradation in Li ion Batteries. Science, 342, 716-720. https://doi.org/10.1126/science.1241882

[21] Shimoi, N., et al. (2015) Mechanochemical Approaches to Employ Silicon as a Lithium-Ion Battery Anode. AIP Advances, 5, Article ID: 057142. 
https://doi.org/10.1063/1.4921563

[22] Li, X., et al. (2015) Germanium Anode with Excellent Lithium Storage Performance in a Germanium/Lithium-Cobalt Oxide Lithium-Ion Battery. ACS Nano, 9, 1858 1867. https://doi.org/10.1021/nn506760p

[23] Wang, K.-X., et al. (2015) Surface and Interface Engineering of Electrode Materials for Lithium-Ion Batteries. Advanced Materials, 27, 527-545. https://doi.org/10.1002/adma.201402962

[24] Jung, S.C., et al. (2014) Sodium Ion Diffusion in $\mathrm{Al}_{2} \mathrm{O}_{3}$ : A Distinct Perspective Compared with Lithium Ion Diffusion. Nano Letters, 14, 6559-6563. https://doi.org/10.1021/nl503169v

[25] Li, J., et al. (2014) Artificial Solid Electrolyte Interphase to Address the Electrochemical Degradation of Silicon Electrodes. ACS Applied Materials \& Interfaces, 6, 10083-10088. https://doi.org/10.1021/am5009419

[26] Lee, D.J., et al. (2013) Nitrogen-Doped Carbon Coating for a High-Performance $\mathrm{SiO}$ Anode in Lithium-Ion Batteries. Electrochemistry Communications, 34, 98101. https://doi.org/10.1016/j.elecom.2013.05.029

[27] Suryanarayana, C. (2001) Mechanical Alloying and Milling. Progress in Materials Science, 46, 1-184. https://doi.org/10.1016/S0079-6425(99)00010-9

[28] Tanaka, Y., Zhang, Q. and Saito, F. (2003) Mechanochemical Dechlorination of Trichlorobenzene on Oxide Surfaces. The Journal of Physical Chemistry B, 107, 11091 11097. https://doi.org/10.1021/jp0276808

[29] Beyer, M.K. and Clausen-Schaumann, H. (2005) Mechanochemistry: The Mechanical Activation of Covalent Bonds. Chemical Reviews, 105, 2921-2948. https://doi.org/10.1021/cr030697h

[30] Welham, N.J. (1998) Mechanochemical Reduction of $\mathrm{FeTiO}_{3}$ by Si. Journal of Alloys and Compounds, 274, 303-307. https://doi.org/10.1016/S0925-8388(98)00590-8

[31] Zhang, Q., et al. (2002) Sulphidization of Metal Oxides by Means of Mechanochemical Solid Reaction. Chemistry Letters, 31, 1094-1095.

https://doi.org/10.1246/cl.2002.1094

[32] Shengqi, X., et al. (1996) The Reduction of CuO by Si during Ball Milling. Journal of Materials Science Letters, 15, 634-635. https://doi.org/10.1007/BF00579274

[33] Bernard, F., Souha, H. and Gaffet, E. (2000) Enhancement of Self-Sustaining Reaction $\mathrm{Cu}_{3} \mathrm{Si}$ Phase Formation Starting from Mechanically Activated Powders. Materials Science and Engineering: A, 284, 301-306.

https://doi.org/10.1016/S0921-5093(00)00749-8

[34] Jolly, F., et al. (1999) Temperature Effects on the $\mathrm{Si} / \mathrm{SiO}_{2}$ Interface Defects and Suboxide Distribution. Journal of Non-Crystalline Solids, 245, 217-223. https://doi.org/10.1016/S0022-3093(98)00864-3

[35] Nagao, Y., et al. (2004) Structural Analysis of Pure and Electrochemically Lithiated $\mathrm{SiO}$ Using Neutron Elastic Scattering. Journal of the Electrochemical Society, 151, A1572-A1575. https://doi.org/10.1149/1.1787173

[36] Hohl, A., et al. (2003) An Interface Clusters Mixture Model for the Structure of Amorphous Silicon Monoxide (SiO). Journal of Non-Crystalline Solids, 320, 255 280. https://doi.org/10.1016/S0022-3093(03)00031-0

[37] Mamiya, M., et al. (2001) Preparation of Fine Silicon Particles from Amorphous Silicon Monoxide by the Disproportionation Reaction. Journal of Crystal Growth, 229, 457-461. https://doi.org/10.1016/S0022-0248(01)01202-7

[38] Hwa, Y., et al. (2013) Modified SiO as a High Performance Anode for Li-Ion Bat- 
teries. Journal of Power Sources, 222, 129-134.

https://doi.org/10.1016/j.jpowsour.2012.08.060

[39] He, M., et al. (2014) Monodisperse Antimony Nanocrystals for High-Rate Li-Ion and Na-Ion Battery Anodes: Nano versus Bulk. Nano Letters, 14, 1255-1262. https://doi.org/10.1021/nl404165c

[40] Larcher, D., et al. (2007) Recent Findings and Prospects in the Field of Pure Metals as Negative Electrodes for Li-Ion Batteries. Journal of Materials Chemistry, 17, 3759-3772. https://doi.org/10.1039/b705421c 